\section{White House \\ Conference update}

\author{
By Patricia A. Wand
}

Chair, ACRL Task Force on WHCLIS

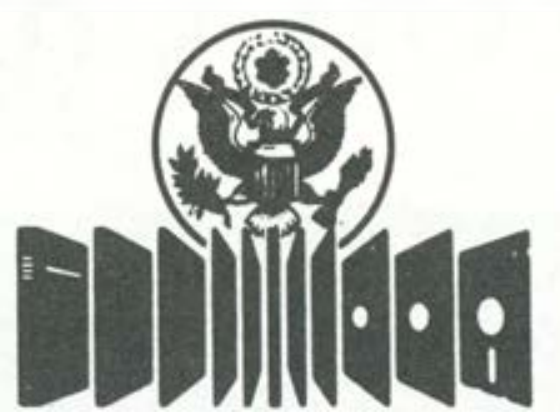

The White House Conference ON LIBRARY AND INFORMATION SERVICES 1991
From across the country librarians converged on Washington, D.C., for Library Legislative Day on Tuesday, April 24, 1990. The agenda was federal support of libraries and that, of course, included talk about the White House Conference on Library and Information Services (WHCLIS) scheduled for July 1991.

Senator Tom Harkin (D-IA), in his briefing of librarians, announced that as chair of the Senate Labor-HHS-Education Appropriations Subcommittee, he would include additional funding for WHCLIS through the Supplemental Appropriations Bill (Senate HR4404). That bill passed the Senate with an additional $\$ 425,000$ allocated to the White House Conference. If the bill passes through the House-Senate negotiations, the supplemental budget will increase to $\$ 2$ million the amount earmarked for states and territories to carry out their preconference activities.

Most states and territories have now scheduled preconference activities. Those planning events in calendar year 1990 are:

- Illinois, April 4-6

- American Samoa, April 11-12

- Nevada, May 10-11

- Connecticut, May 22-24

- Michigan, May 31-June 1

- Georgia, September 5-6

- Hawaii, September 7-8

- Pennsylvania, September 13-15

- Minnesota, September 16-17

- Maryland, September 23-25

- Louisiana, September/October

- New Jersey, September or December

- Colorado, October 8-10

- West Virginia, October 11-13

- Tennessee, October 14-16

- Marshall Islands, October

- Northern Marianas, October

- Ohio, Fall

- Puerto Rico, November 6-8

- Indian Tribes, November 8-9

- Kansas, November 8-10
- Virginia, November 10-11

- Guam, November 15-17

- Missouri, November 16-17

- Indiana, November 16-18

- New York, November 28-30

- North Dakota, November 29-December 1

- Oklahoma, November 30-December 1

- Federal Library Community, November

- Florida, December 3-5

Several states have tentative dates set and others have not yet determined their preconference activity schedule. As an example of the focus that discussions may take, the stated objectives of the Illinois pre-White House Conference on Libraries and Information Services were:

- develop issues and questions relative to the delivery and use of information in Illinois;

- study new information technologies and their potential in Illinois;

- discuss the role for Illinois libraries in providing information for literacy, productivity, and democracy.

Academic librarians in all states may contact their state libraries to learn the details of events.

\section{EBSS Newsletter editor needed}

The ACRL Education and Behavioral Sciences Section requires an interested individual to keep EBSS members informed through the section's newsletter. Please send a letter of interest and a sample of editorial/newsletter work to Pam Baxter, Psychological Sciences Library, Peirce Hall, Purdue University, West Lafayette, IN 47907. Applications will be reviewed at ALA Annual Conference. The editor will begin production with the Fall 1990 issue, scheduled for mailing prior to the 1991 Midwinter Meeting. 


\section{You can have it all.}

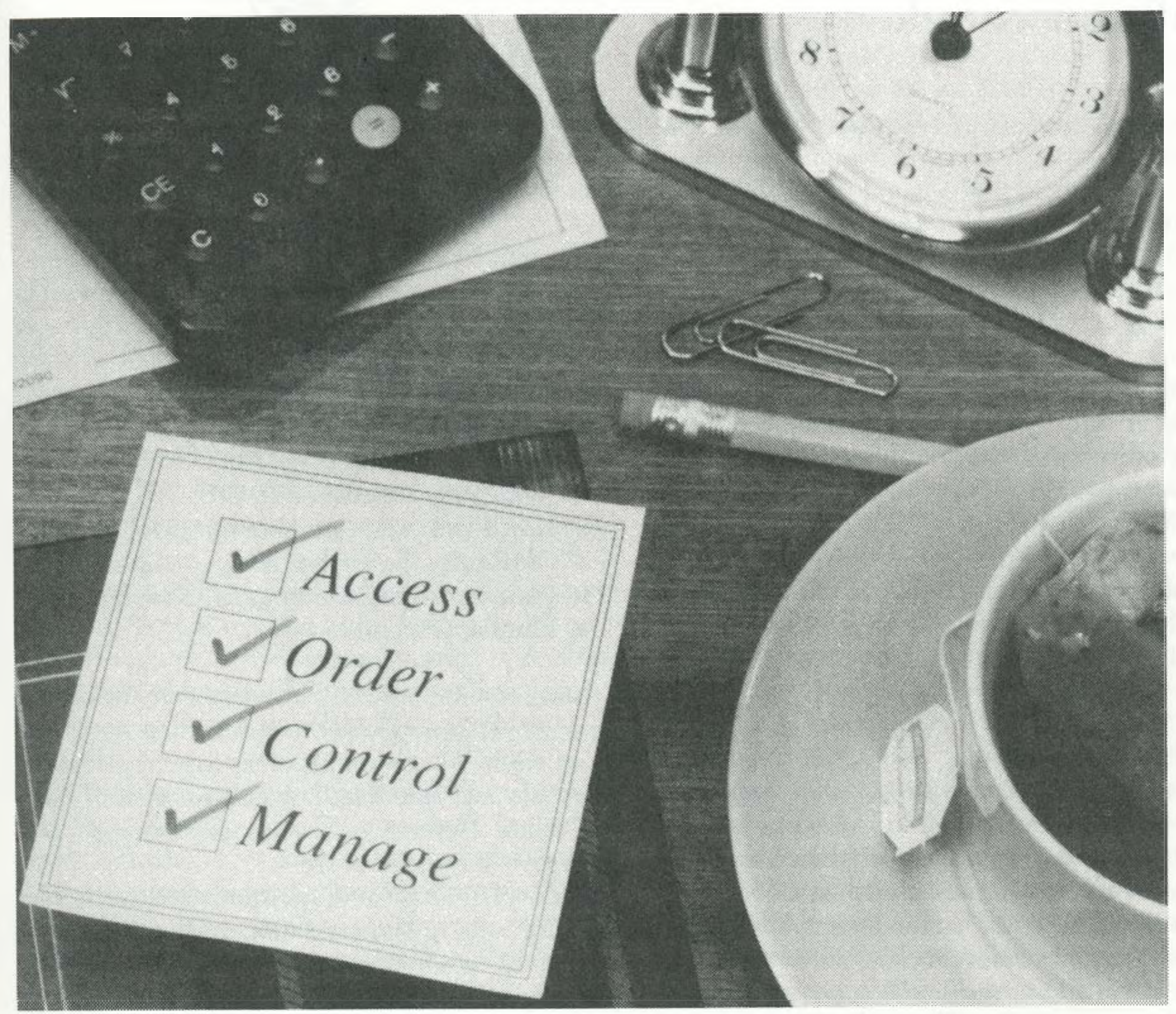

Others can place your order, but only Faxon provides a complete line of serials acquisition and management services to guide you through every step of your purchasing cycle. Our accurate pricing information facilitates budgeting and planning, while other Faxon services simplify ordering and renewal, speed check-in and claiming, and provide fast, easy access to all the information you need.

Start putting Faxon's comprehensive set of services to work for you. Call today at 1-800-225-6055. (In MA, call 617-329-3350 collect.) 